\title{
The Impressionistic Expression Technique in Shakespeare's Comedy "Much Ado About Nothing"
}

\author{
Hao Yan \\ Ordos College of Inner Mongolia University, Kangbashi New District of Ordos in Inner \\ Mongolia 017000, China
}

Keywords: Shakespeare; "Much Ado About Nothing"; Impressionistic; Comedy

\begin{abstract}
Much Ado About Nothing" is a mature comedy of Shakespeare, which has a unique style and strong artistic appeal. Shakespeare has a bright present as "the great psychologist" in the play, and he understands and deals with the contradiction of love from psychological point of view, which makes the impossible possible, and shows the comedy skills of the genius. In addition, the multiple application of illusion is the feature of this comedy. Using the dislocation of truth and illusion rendering to create comedy is the show's unique style, thus forming a different style. This paper explores the impressionistic expression technique in Shakespeare's comedy "Much Ado About Nothing".
\end{abstract}

The author of "Much Ado About Nothing", Shakespeare, is a famous British writer in European Renaissance. He not only has outstanding achievements in drama, also is known as "the greatest psychologist". Because human psychology is very difficult to grasp, the true measure of genius writer is if the works can carefully express the characters' inner emotional expression. Goethe made a comment on Shakespeare's accomplishment in psychology: "From his works, I could learn to understand human thoughts and feelings, and he is a great psychologist". "Much Ado About Nothing" sufficiently shows Shakespeare's psychological control of the characters for readers, and skillfully applies his talent in this aspect to incisively and vividly show the emotional change of the character in the work.

In it, the love psychology between Bert Liz and Penny Dick is worth readers' pondered, and the two roles are the most successful and most vivid task roles shaped by Shakespeare in "Much Ado About Nothing". The author has spent a lot of words to depict their mental activity, and make the two characters become so bright and so full. Author Shakespeare with his keen insight into the character's psychology, let the reader feel the beauty of love between Bert Liz and Penny Dick, which better serves his impressionistic expression.

Betty Liz and Penny Dick are noble young men, who are very cute, but very proud. Penny Dick is cheerfully generous, but detests evil, which is very proud, and has a deep negative marriage idea. He thinks that marriage is his bondage, and this stereotype marriage idea is held by women and men who haven not got married. In "Much Ado About Nothing", Claudio points out that the thought is completely without the experience of love flame. Once experienced, these ideas are completely ceased to exist. Betty Liz is a carefree and optimistic woman. In the works of Shakespeare, he describes this kind of carefree that she will laugh awake in her dream. But such a woman looks down upon the man, and she thinks that men are made of mud. Why does a woman want to own life to do things entrusted to mud, and intends to be lower in front of them? So these two characters that are very close to each other in the book will have inevitable collision and friction. And these two people end up together. Shakespeare's impressionistic expression let a person feel puzzling, and makes readers in the elusive. As if he has a magic wand, Shakespeare is good at making what the others think impossible possible. In literary works, psychological activities of the characters are very big. It is very difficult to describe two similar personalities, their proud characters, and friction and collisions between their pride personality and at the end of the process, love. But Shakespeare successfully solved the seemingly difficult problems, and let it looks very challenging and dramatic. He found the solution to the problem from the angle of psychology. Same personality people, just like two magnets, repel each other. On the one side, they attract each other, and they contradict each other on the other hand. Men and women are attractive to the opposite sex, which is a person's real psychology. Shakespeare's clever use of this let the story so reasonable. It wins no simple 
astounding.

"Much Ado About Nothing" has been around two love affairs ---- Claudio and Hiro are on behalf of the traditional class's portal idea of marriage; Pearson's Dick and Betty Liz perform the true love bud in mutual confrontation interest. Through comparing two kinds of love, we can find Shakespeare's impressionistic expression. Under patriarchy and male domination, traditional marriage is based on social norms label like class, property and others. It is easy to understand its fragility. Claudio and Penny Dick's talk shows his love for Hiro, but before marriage, he first asked prince Aragon Peter Luo Hiro's family.

In this work "Much Ado About Nothing", there is such a dialogue, Claudio: your highness, now I ask you a favour.

Peter: we are good friends. Tell me if I can do anything for you, no matter how difficult it is, I will try to help you. Claudio: your highness, does Leo has a son? Peter: no, Hiro is his only heir. Do you really like her, Claudio? From this conversation, Claudio confirmed Hiro was the only daughter of the governor, which means that Hiro can inherit all of her father's property. A few words of love have a reason to determine love suddenly, and Claudio then issued a declaration of love for Hiro:

Claudio: ah, your highness, when we set out to battle, I looked at her with military eyes. Although heart is willing, because of more hard work in front of me, I cannot think about love; Now I come back. The thought of war has left my mind, instead of it is her tenderness, which shows me how beautiful young Hiro is, and says to me that I had fallen in love with her before the war.

Property, family matters are over. Claudio proposed step by step in accordance with the traditional etiquette. Delegate Peter Luo is the matchmaker, who is waiting for the father's response. Behind a set of red tape is the feudal idea on Claudio. On the one hand of Hiro, Betty Liz and her father's dialogue let readers see her as a good family lady. Antonio: (to Hiro), niece, I believe you must listen to your father. Betty Liz: yes, my sister should know the rules, "father, I will follow your idea." But although she says so, sister, he better be a pretty guy, otherwise you can say, "father, I'd like to make my own decision."

The communication between Claudio and Hiro is extremely limited. Right before marriage, that marriage with no emotional foundation was destroyed by a prank. Claudio shows strong possessive instinct over Hiro. When he "sees" her "affair" with others, he decided to insult the bride at the wedding when he is not sure about the fact. The distrust and lack of understanding between each other shows that the marriage has no love. When Hiro grievances are clarified, she still chooses to marry Claudio, which is because of the ideological thinking of "stick to one" in patriarchal society. After twists and turns, Claudio and Hiro eventually married. But the real leading roles in the play are Penny Dick and Betty Liz. Their love is lighted up with flashes of humanism. Penny Dick and Betty Liz's appearance always begins with a quarrel, and ends with a quarrel. But as you can see, the cynicism cannot leave each other as an object. Argument is, as it were, the two young people's love camouflage. They don't know pure love has already occurred, and true love has no purpose, and is shy to tell. The drama begins with messenger's words.

In balls, Penny Dick and Betty Liz are partners of each other, while Penny Dick already knows Liz's identity. Betty Liz starts a conversation with Penny Dick, and then a series of disparaging remarks. After left the party, Penny Dick was annoyed! Penny Dick: oh, she insulted me so bad that a piece of stone would jump straight! One bald oak tree with a piece of green leaf could not help but argue with her; my face mask is about to be alive by her scold. She did not know I was in front of her, and she said to me, I am a prince, and I'm more bored than melting snow weather. Her words are like disorderly arrows, and I was like a target. Her every word pierces into my flesh. Who dare to marry such a woman? She will call Hector Sophocles barbecue for her, and break his stick as wood to burn. Ok, forget about her. She is the disguised dragon, so all the chaos, terror, ado are following her along. Without the interference of love, why would Penny Dick who is always cool care about it? In "Much Ado About Nothing", hacking and trap are indispensable. A bunch of people such as Peter Luo set a trap for eavesdroppers----Penny Dick holding the culture of celibacy and Betty Liz talking her husband as a joke---- to be in love of each other. Like paper thin, Penny Dick and Betty Liz's ridicule and pride vanished into thin air. They become "conscious" about each other's love, and they 
began to reflect on their own heart. The true feeling really emerged.

It can be seen that: love follows the law of nature. "Misogyny" Penny Dick and "misandria" Bert Liz also could not prevent the operation of law. They all embody the praise of "celibacy" and fight against marriage behavior. Shakespeare makes them betray themselves ---- asceticism flags eventually in the development of love, and love is the true pursuit of humanism. Unravel the behavior of self-deception in forms of comedy, and single bucket also cannot fight gentle love.

Hiro and Betty Liz's love ends happily, but the former is not so brilliant as the latter. Polite marriage makes the beauty lose color, and Hiro's character has always been like an invisible man which is very weak. In contrast, Liz has bold freedom. Under the love moist, the lovely woman is more mature. Through a pair of hero beauty and the love course of comedy duo, Shakespeare shows his sarcasm and discontent about the traditional marriage pattern with impressionistic expression technique; In his view, the sincere love is established on the basis of humanism, which is simple love not restricted by feudal constrains between two who trust each other----like the combination of dear Betty Liz and Penny Dick.

Much Ado About Nothing's drama is reflected basically from characters and psychological activities, and the author uses impressionistic expression technique to explode collisions between personality and psychological character to produce the effect of comedy.

REFERENCE

[1] Li Weiming. Huangmei opera in post-classical narratology: Shakespeare's comedy "Much Ado About Nothing" [J]. Journal of Anhui Normal University (Humanities and Social Science Edition), 2010,06: 677-682.

[2] Lou Suqin. "Much Ado About Nothing"'s comic art analysis [J]. Journal of Xinxiang College (Social Science Edition), 2008-01:105-107.

[3] Li Qiaoli. The contradiction narrative inquiry of "Much Ado About Nothing" [J]. Journal of Mudanjiang Normal University (Philosophy and Social Sciences Edition), 2014-01:93-95.

[4] Zhang Zhiyan. Castle mobile comic feast -- Shakespeare "Much Ado About Nothing" evaluation [J]. Journal of Sichuan Drama, 2012,06: 59-60. 